\title{
Research on Application of New Media in Expanding Approaches for College Network Ideological and Political Education
}

\author{
Yunzhi Li, Baoyi Zhang \\ College of Computer Science and Technology, Shandong University of Finance and \\ Economics, Ji'nan, 250014, China
}

\begin{abstract}
In this paper, the author will discuss the application of new media in expanding new approaches for college network ideological and political education, make positive and effective improvement to the current situation of college network ideological and political education, give full play to positive action of new media, and really improve the effect of contemporary college network ideological and political education.
\end{abstract}

Key words: new media, college students, network ideological and political education, expansion of educational channel

\section{Preface}

Under the environment of new media, network ideological and political education is of great significance for Chinese college students. Many education competent departments also began to try different educational methods. Under such situation, China's college network ideological and political education has already obtained certain achievements. However, it also brought forth new challenges to education. Thus, it is necessary for us to envisage the current situation of college network ideological and political education, make timely renewal to educational philosophies and teaching contents, fully utilize all kinds of new multimedia technical means, positively expand new approaches for network ideological and political education, and allow network ideological and political education for Chinese college students to obtain better educational effects under the assistance of new media.

2. Analysis on current situation and issues of network ideological and political education for Chinese college students

For boring ideological and political education for college students, network has great advantages. To be specific, network has the feature of resource sharing. Schools can take full advantage of campus network to perform ideological and political education for students and issue some information to educate and guide students accordingly, so as to improve the effectiveness of ideological and political education for students in colleges and universities. At the same time, network is more vivid and interesting. It can attract the attention of young students in a better way, letting college students autonomously perform ideological and political education. Besides, network is also featured by information copying and timeliness. It can make the work of network ideological and political education for college students to be more socialized. Therefore, many colleges and universities developed network ideological and political education for college students. Viewed from the current situation, however, there are 
also some issues that can not be neglected.

(1) Websites of ideological and political education in colleges and universities lack outstanding advantages. In China, many colleges and universities have already established websites of ideological and political education for college students. However, their functions are not given fully play to. The reason is that the educational pattern is also very traditional and conventional for websites of college student ideological and political education in many colleges and universities. Moreover, the educational method is too simple. The educational pages of the entire website lack proper appetency. As a result, the educational effects are made to be very difficult to be effectively improved. The overall education is not strong. Some colleges and universities even failed to set up the ideological and political education platform under the network environment. Students failed to sufficiently learn and master the contents in this part.

(2) Network ideological and political education for college students has insufficient guidance for students. The work of ideological and political education in Chinese colleges and universities is confronted with more complicated domestic and international situation. Competitions between enemies and us are still very fierce. Many hostile forces disseminated various kinds of bad information through the network platform, so as to erode ideological and political conditions of young Chinese students. However, the network ideological and political education in Chinese colleges and universities failed to make positive and effective response. Some decadent values of the capitalist class were spread among college students, thus displaying insufficient network ideological and political education in Chinese colleges and universities.

(3) Colleges and universities failed to effectively monitor network culture. Network is an open world filled with all kinds of information and ideas. Many people in different backgrounds will communicate different kinds of information on the Internet. Therefore, we are unable to exclude the appearance of some vulgar and even reactionary information on the Internet. Thus, it is easy to make college students without completely shaped values and views of life to suffer from ideological pollution. We must enhance the degree of monitoring for network culture.

\section{Overview of new media}

The present world is an information times. Under the participation of new media, dissemination of information becomes faster and more convenient. Therefore, new media have already penetrated into all aspects of social economy, politics, culture and life. That is to say, human society has already entered a new media time. Ideological and political educators in colleges and universities should comply with such era development trend and tightly grasp characteristics of the times of new media. For instance, the medium integration of colleges and universities has huge energy and tool-type neutral features, leading college students to set up correct ideological values, improving ideological and political attainment of college students and making college students to become excellent successors and constructors of socialist cause with Chinese characteristics. 
Then, what is so-called new media? Firstly, we should make it clear for the definition of medium. The work of medium was from Latin at the earliest. It refers to an information transmission platform, including material substance of information transmission and overall contents of transmission. Therefore, medium is an information carrier with certain values. On the basis of the definition of medium, we analyzed the concept of new media. Up to now, the definition of new media has not been unified. We summarized several influential views in China. New media refer to new patterns of media established on the basis of digital technology, network technology and mobile communication technology. Many people divided new media like this: newspapers and periodicals belong to the first media. Broadcast belongs to the second media. Television is called the third media. The Internet is termed as the fourth media. Mobile network represented by mobile phone becomes the fifth media with its strong advantages. The first three media are called traditional media. The latter two media are termed as new media. The connotation of new media mainly includes two levels of meaning: digital media at the technical level and radial reform of relations between human and information at the philosophical level. Its transmission process has the following basic features: equality and freedom of subject, timeliness and magnanimity of content, formal digitization and interaction, fragment and virtualization of context, service individuation and sharing of readers and audiences.

For new media, the future trend is presented as follows: more complicated interaction, gradually intensified integration and transformation from "invasion into audiences" to "invaded by audiences". Integration and merger speeded up the socialization process of new media. Therefore, new media are of certain values for ideological and political education for contemporary college students. Specifically, new media eliminated borders of traditional media, letting information senders and receivers break various borders for communication and exchange, greatly eliminating borders of traditional media, and realizing real-time transmission. Thus, college students with strong self-consciousness are allowed to obtain the most ideal channels of information source, beneficial for eliminating estrangement between students and teachers and improving the efficiency of ideological and political education. At the same time, new media are also featured by hypermedia, which can attract the attention of young college students. They can obtain a great many of words and pictures and even videos through mobile phone and other receiving terminals. Such new media information obtaining mode is faster and more convenient, interesting and comprehensive, which has strong attraction for college students. At the same time, it can also implement wide penetration among college students and finally obtain profound radiation.

\section{Application of new media in expanding new approaches for network ideological and political education for college students}

Under the background of new media, the network ideological and political education is of great importance for Chinese college students. Many colleges and universities are seeking for new 
network education camps. With the arrival of the times of new media, great changes took place in objects of network ideological and political education for college students and network behaviors of college students. Therefore, we must take full advantage of new media to expand new approaches for network ideological and political education for college students.

(1) For network ideological and political education for college students, new media should be utilized to pass on positive ideological energy among college students. Under the background of new media, great changes took place in the ideological and political education for college students. Therefore, ideological and political education workers should comply with the development trend of times, firmly grasp network \& social intercourse behavioral characteristics of college students, give positive guidance to ideology and politics of college students and effectively improve overall effects of network ideological and political education for college students. Then, we can utilize new media for strong connection and give play to positive energy among peers of college students. It is of greater degree of freedom for communication and exchange between them, with stronger sense of trust. It is easier for college students to accept their values and ideological education. Moreover, we can utilize new media to perform strong connection among college students, letting college students input more positive and effective network information. We can display dome advanced typical figures or things to college students through new media and allow friends with bidirectional information transmission port to positively pass on information, so as to be beneficial for really motivating positive energy of the network ideological and political education for college students.

(2) Network ideological and political education for college students should utilize new media to guide college students to enhance the resolving ability. Under the background of new media, network ideological and political education for college students should give full play to the function of some weakly connected friends, let great gap between them to be fully presented, and communicate and exchange some different information contents, beneficial for arousing ideological and political thoughts of college students in a better way, triggering them to make deep reflections and enhancing their ability to distinguish between right and wrong. It is relatively easy for information obtaining approaches under such new media. It more relies on strongly connected friends. Therefore, many college students are different from each other in terms of ideological and political condition. Sometimes, they basically relied on judgment of strongly connected friends. Then, college students are made to consider ideology and politics from different aspects, if we can obtain different information contents of these weakly connected friends. With rapid development and expansion of network, the work of ideological and political education for college students is made to be rapidly spread under the environment of new media. Once college students are involved in negative ideological and political emotions, we can change their ideological and political condition, enhance their trust for weakly connected friends, narrow the distance between people and people, and promote the combination of mutual benefits through different information contents brought forth by weakly 
connected friends.

(3) Network ideological and political education for college students should utilize new media to balance network and social activities of college students. Under the background of new media, ideological and political education workers in colleges and universities should take full advantage of technical tools and network platforms of new media to perform positive guidance for college students, letting college students master the most basic network and social behaviors. The reason is that network behaviors of college students are featured by diversification under the network environment. Thus, it is necessary for network ideological and political education workers to give instructions to college students in terms of weakly and strongly connected friends, so as to let them understand actual conditions of the objects of their network and social activities and emphasize obtaining more positive energy in network and social activities. This is an important link for optimization and improvement of network ideological and political education for college students. We must allow college students to realize different actions of weakly and strongly connected friends under the times of new media and make great efforts to make the actions of the two items to reach effective balance. Or, college students will be easily caused to have simple and boring ideological and political conditions and lack necessary innovative consciousness, if they only paid attention to communication with strongly connected friends. However, they will also gradually loose the collective consciousness, if they only received communication information from weakly connected friends. Moreover, this will be further enlarged in the network environment. Therefore, college student network ideological and political education workers in colleges and universities should attach importance to finding out the balance point for communication with different friends and make efforts to promote continuous optimization to the network ideological and political education environment.

(4) Network ideological and political education for college students should utilize new media to develop corresponding work of ideological and political education. Ideological and political education for college students should break through all kinds of old concepts, utilize network environment and network technical platforms of new media to develop corresponding ideological and political education for college students, make such education to show greater advantages and features, improve market competitiveness of network ideological and political education for college students, and make continuous improvement to its influence among college students. We should develop ideological and political education works with different characteristics among different college students, help them to gradually cultivate good network behavioral habits, and effectively prevent them from suffering from influence of adverse ideological contents and network behaviors, so as to avoid some behaviors of moral abnormality to a large extent. Therefore, colleges and universities should take full advantage of new media to perform positive advocacy of ideological and political education among college students, guide them to love the collective and gradually integrate into the cultural life on college campus, intensify their self-conscientious in network and standardize their behavioral 
pattern of democratic participation. Moreover, network ideological and political education for college students should also positively guide college students to set up correct values and views of life, allow them to continuously explore for deeper moral standards while contacting all kinds of fresh things and objects, and weaken college students' attention to and interests for some negative information. Certainly, primary network ideological and political education for college students should also improve the overall information literacy of college students (i.e. excellent information consciousness, information ability and good information morality), so as to let them provide more positive ideological and political information to college students in the practical education works and truly become high-quality ideological and political education workers under the times of new media.

\section{Conclusion}

To sum up, we should fully utilize new media for the network ideological and political education for college students, allow network to become an effective expansion channel used by college students for social course in reality, attach importance to giving full play to different functions of strong and weak friends in the network, make great efforts to create a healthy social networking services environment for college students, and make continuous improvement to the network ideological and political education environment for college students, so as to allow college students to be in a vibrant ideological and political education environment, continuously expand the dimension and depth of the network ideological and political education for college students, guide college students to make independent and positive judgment and selection in the complicated network environment, and improve the effect of the overall network ideological and political education for college students.

\section{References:}

[1] Dai Yongjian and Wang Feng, Influence and Enlightenment of New Media Technology on Thoughts of Contemporary College Students [J], Economic and Social Development, 2011 (11);

[2] Dou Jia, Research on College Ideological and Political Education Transmission Strategies in the New Era under the View of Communication [D], Xi'an: Northwest University, 2010;

[3] Xu Haixin and Liao Haojun, Analysis on Effective Function of New Media in College Ideological and Political Education [J], Academic Forum, 2011 (7) 